\title{
Effects of chlorine dioxide on morphology and ultrastructure of Fusarium sulphureum and its virulence to potato tubers
}

\author{
Li Mei ${ }^{1 *}$, Tian Shilong ${ }^{1}$, Shen Jin ${ }^{2}$, Wang Xizhuo ${ }^{2}$, Cheng Jianxin ${ }^{1}$, \\ Li Shouqiang ${ }^{1}$, Ge Xia ${ }^{1}$, Tian Jiachun ${ }^{1}$
}

(1. Agricultural Product Storage and Processing Research Institute, Gansu Academy of Agricultural Sciences, Lanzhou 730070, China; 2. Chinese Academy of Agricultural Engineering, Beijing 100125, China)

\begin{abstract}
The inhibitory effect and its virulence of chlorine dioxide $\left(\mathrm{ClO}_{2}\right)$ against dry rot of potato were investigated. Potatoes were treated by $\mathrm{ClO}_{2}$, then observed for indoor bioassay, scanning electron microscopy (SEM) and transmission electron microscopy (TEM) were used to observe the morphology and ultrastructure of hyphae, and evaluated the control efficiency of $\mathrm{ClO}_{2}$ on potato tuber (LK99) dry rot by F. sulphureum pre-treatment. The results showed that the pathogen of potato dry rot was sensitive to $\mathrm{ClO}_{2}$, the virulence of regression of $y=5.05+7.308 x, \mathrm{EC}_{50}$ and $\mathrm{EC}_{90}$ were 0.3490 and 0.6261 respectively, the treatment of $\mathrm{ClO}_{2}$ could significantly inhibit the spore germination and mycelium growth of $F$. sulphureum, which was in a concentration-dependent manner, SEM and TEM observed that the morphology and ultrastructure of $F$. sulphureum hyphae were regularly damaged by $\mathrm{ClO}_{2}$, in vivo experiment further indicated that $\mathrm{ClO}_{2}$ could effectively control the dry rot of potato tubers with $F$. sulphureum, and $\mathrm{ClO}_{2}$ at the concentration of $0.75 \mathrm{ug} / \mathrm{mL}$ could significantly reduce the incidence of potato tuber dry rot and lesion expansion rate. The study showed that $\mathrm{ClO}_{2}$ could greatly against the pathogen of F. sulphureum, which could provide a scientific theoretical basis for the safe and efficient application of $\mathrm{ClO}_{2}$ in the prevention and control of potato diseases after harvest.
\end{abstract}

Keywords: potato, dry rot, chlorine dioxide, Fusarium sulphureum, virulence, morphology and ultrastructure DOI: $10.25165 /$ j.ijabe. 20171005.2403

Citation: Li M, Tian S L, Shen J, Wang X Z, Cheng J X, Li S Q, et al. Effects of chlorine dioxide on morphology and ultrastructure of Fusarium sulphureum and its virulence to potato tubers. Int J Agric \& Biol Eng, 2017; 10(5): 242-250.

\section{Introduction}

Potato is widely cultivated throughout the world, there are more than 160 countries to plant potatoes ${ }^{[1]}$. With greater emphasis on food security in recent years, the planting area and yield of potatoes appear an increasing trend, which has become one of the main economic crops in adjusting the planting structure of

Received date: 2016-01-28 Accepted date: 2017-03-16

Biographies: Tian Shilong, BE, Senior Agronomist, research interests: agricultural products storage and processing, Email: tianshilong@gsagr.ac.cn; Shen Jin, Master, Professor, research interests: agricultural engineering, Email: shenjin2511@163.com; Wang Xizhuo, Master, Associate Professor, research interests: agricultural products storage and fresh-keeping, Email: wxz3910@163.com; Cheng Jianxin, Master, Research Associate, research interests: agricultural products storage and processing, Email: chenjianxin@ foxmail.com; Li Shouqiang, BE, Associate Professor, research interests: agricultural products storage and
China, elevating agriculture efficiency and raising farmers' income ${ }^{[2]}$. But at least $20 \%-25 \%$ of potatoes are rotted because of pathology and physiological factors after harvest in China, which cause an extremely serious economic loss every year ${ }^{[3]}$. Dry rot of potato caused by Fusarium is the most common in the store, account for more than $50 \%$ of fungal diseases in the store. And Fusarium sulphureum is the main pathogens brought dry

fresh-keeping, Email: lishouqiang@gsagr.ac.cn; Ge Xia, ME, Associate Professor, research interests: agricultural products storage and fresh-keeping, Email: gexia@gsagr.ac.cn; Tian Jiachun, $\mathrm{PhD}$, Research Associate, research interests: agricultural products storage and processing, Email: tianjiachunlz@126.com.

* Corresponding author: Li Mei, ME, Associate Professor, research interests: agricultural products storage and processing. Agricultural Product Storage and Processing Research Institute, Gansu Academy of Agricultural Sciences, Lanzhou 730070, China. Tel: +86-13893148383, Fax: +86-931-7683537, Email: limei7877@126.com. 
rot of potato in the northwest of China ${ }^{[1]}$. Reducing the trauma during harvest, storage and transportation, or storing potatoes in the environment are in favor of healing of trauma to control the infection of pathogens, all of which could prevent the dry rot of potato tuber. Normally, the chemical synthetic fungicides thiabendazole after the harvest is mainly used. However, the resistance to thiabendazole is generally increased, such as Fusarium sambucinum, moreover, the problems of pesticide residues and environmental pollution are widely concerned $^{[4]}$. In recent years, some natural and generally recognized as safe (GRAS) chemical compounds, such as chitosan ${ }^{[5]}$, nitrite ${ }^{[6]}$, borate $^{[7]}$, sodium silicate ${ }^{[8]}, \beta$-aminobutyric acid ${ }^{[9]}, \mathrm{K}_{2} \mathrm{HPO}_{4}{ }^{[10]}$ and citric $\operatorname{acid}^{[11]}$, can effectively control the dry rot of potato tuber, but most of these chemical compounds are in the laboratory research stage, and difficult to apply in production due to the cost. Therefore, it is important to develop the new type of preservatives of low poison, low cost and high efficiency, to prevent the dry rot in storage. As a strong oxidant, $\mathrm{ClO}_{2}$ is an $\mathrm{A} 1$ level broad-spectrum, which is efficient and safe disinfectant of sterilization and preservation that recommended worldwide by WHO and FAO, and also be approved by FDA as the recognized food preservative ${ }^{[12]}$. $\quad \mathrm{ClO}_{2}$ could be rapidly adsorbed on the surface of dangerous organisms, effectively restrain pathogens and reduce the rot of vegetables and fruits. At the same time, no harmful substance and odor residue be produced during the sterilization process of $\mathrm{ClO}_{2}$ application, and it can stay the original flavors of processed fruits and vegetables without negative influence on the food flavors and appearance quality. Thus, $\mathrm{ClO}_{2}$ is internationally recognized as the excellent performance and much better effected food preservative ${ }^{[13]}$. In addition, $\mathrm{ClO}_{2}$ can effectively prevent methionine to synthetizing ethylene in fruits and vegetables, and destroy the synthetic ethylene, to delay fruit senescence and long-term fresh fruits and vegetables ${ }^{[14]}$. At present, most researches about $\mathrm{ClO}_{2}$ disinfection is still concentrated on drinking water and microorganisms of food surface. However, virulence and control function of $\mathrm{ClO}_{2}$ treatment on pathogens after harvest of fruits and vegetables, especially on potato pathogen are rarely reported. Therefore, this article mainly studied the virulence and control function of $\mathrm{ClO}_{2}$ treatment on the dry rot of potato tuber after harvest through experiment in vivo and vitro, which would provide the theoretical basis for further inhibitory of $\mathrm{ClO}_{2}$ on dry rot of potato tuber after harvest.

\section{Materials and methods}

\subsection{Potato tubers and chemicals}

Potato (Solanum tuberosum cv. LK99) was harvested from Huichuan Test Station, Weiyuan County of Gansu Province of China. The potato tubers of uniform size and absence of physical injuries were packed in net bags $(15 \mathrm{~kg} / \mathrm{bag})$ and immediately transported to the laboratory within $24 \mathrm{~h}$ where they were sorted at $3^{\circ} \mathrm{C}-5^{\circ} \mathrm{C}$ and $80 \%$ RH. Before treatment, tubers were surfaced-disinfected with $2 \%$ sodium hypochlorite for $2 \mathrm{~min}$, and then rinsed with tap water and air-dried.

Chlorine Dioxide $\left(\mathrm{ClO}_{2}\right)$ was purchased from Tianjin zhangda technology development co. (Tianjin, China).

\subsection{Pathogen}

The fungal pathogen, F. sulphureum Schlechlendahl, was provided by Institute of Plant Protection, Gansu Academy of Agricultural Science and Technology. Fungal spores were removed from seven-day-old potato dextrose agar (PDA), and suspended in $5 \mathrm{~mL}$ of sterile distilled water containing $0.05 \%(\mathrm{v} / \mathrm{v})$ Tween-80. The suspensions were filtered through 4 layers of sterile cheesecloth in order to remove adhering mycelia and the concentration was adjusted to $1 \times 10^{7}$ spores $/ \mathrm{mL}$ using a hemocytometer.

\subsection{Inhibitory effect of $\mathrm{ClO}_{2}$ on $F$. sulphureum in vitro}

\subsubsection{Indoor bioassay}

In accordance with agar-injection method ${ }^{[15]}$. The sterilization of the agar medium while the liquid poured into the drying and sterilization of $90 \mathrm{~mm}$ diameter dish, $30 \mathrm{~mL}$ per dish, for medium after cooling, using micropipettor with spore concentration of $1 \times 10^{7}$ spores/mL bacterial suspension $100 \mu \mathrm{L}$ after coating plate, then with a sterile metal punch $(d=5 \mathrm{~mm})$ into the hole diameter $5 \mathrm{~mm}$, use a toothpick to remove aseptic hole agar after 1-2 drops of 1\% agar liquid seal the bottom of the hole and in the hole, etc. after condensation with 
different concentrations $\quad(0 \mu \mathrm{g} / \mathrm{mL}, \quad 0.25 \mu \mathrm{g} / \mathrm{mL}$, $0.5 \mu \mathrm{g} / \mathrm{mL}, 0.75 \mu \mathrm{g} / \mathrm{mL}, 1.0 \mu \mathrm{g} / \mathrm{mL}$ and $1.25 \mu \mathrm{g} / \mathrm{mL})$ of preservatives in each hole, immediately sealed with sealing membrane, each treatment was replicated three times, and with sterile water as control. These operations were performed under sterile conditions. Then incubated at $25^{\circ} \mathrm{C}$, the mycelial growth was determined by measuring the colony diameter 5-7 $\mathrm{d}$ after inoculation.

\subsubsection{Spore germination assay}

The effects of $\mathrm{ClO}_{2}$ on $F$. sulphureum spore germination were assayed according to $\mathrm{Li}$ et al. ${ }^{[16]}$. Briefly, $15 \mu \mathrm{L}$ aliquots of conidial suspensions $\left(1 \times 10^{7}\right.$ spores $/ \mathrm{mL})$ were plated on $1 \%$ agar flake $(10 \mathrm{~mm}$ in diameter) mounted with different concentrations $(0 \mu \mathrm{g} / \mathrm{mL}$, $0.5 \mu \mathrm{g} / \mathrm{mL}, 0.75 \mu \mathrm{g} / \mathrm{mL}$ and $1.0 \mu \mathrm{g} / \mathrm{mL})$ of $\mathrm{ClO}_{2}(12 \%$ $\mathrm{ClO}_{2}$ ), and then incubated in Petri dishes at $25^{\circ} \mathrm{C}$. After $8 \mathrm{~h}$ of incubation, germination rates were assessed by observing approximately 200 spores per treatment replicate under a light microscope. Each treatment was replicated 3 times and the experiment was repeated twice.

\subsubsection{Mycelial growth assay}

The effects of $\mathrm{ClO}_{2}$ on $F$. sulphureum mycelial growth were assayed according to Yao and Tian ${ }^{[17]}$. The mycelial disks (10 $\mathrm{mm}$ in diameter) from seven-day-old fungal cultures were placed in the center of the Petri dishes (90 $\mathrm{mm}$ in diameter) with $30 \mathrm{~mL}$ of PDA containing different concentrations of $\mathrm{ClO}_{2}(0 \mu \mathrm{g} / \mathrm{mL}$, $0.5 \mu \mathrm{g} / \mathrm{mL}, 0.75 \mu \mathrm{g} / \mathrm{mL}$ and $1.0 \mu \mathrm{g} / \mathrm{mL}$ ), and then incubated at $25^{\circ} \mathrm{C}$. The mycelial growth was determined by measuring colony diameter seven-day-old after inoculation. Each treatment was replicated 3 times and the experiment was repeated twice.

\subsection{Scanning electron microscopy (SEM) observation}

Hypha samples excised from seven-day-old cultures of the fungi treated with different concentrations $(0 \mu \mathrm{g} / \mathrm{mL}, 0.5 \mu \mathrm{g} / \mathrm{mL}, 0.75 \mu \mathrm{g} / \mathrm{mL}, 1.0 \mu \mathrm{g} / \mathrm{mL})$ of $\mathrm{ClO}_{2}$ were vapor-fixed with $2 \%(\mathrm{w} / \mathrm{v})$ aqueous osmium tetroxide in a Polaron E500 sputter coater (Polaron, Cambridge, England), and then kept in a dessicator for $2 \mathrm{~h}$ at $4^{\circ} \mathrm{C}$, air-dried and sputter-coated with gold palladium until examination with a Cambridge Stereoscan 5-150 SEM (LEO Electron Microscopy Ltd., Cambridge,
England) operating at $20 \mathrm{kV}$. Micrographs were taken with a CCD-Camera (America Gatan Company). The experiment was repeated three times on two replicate plates for each treatment and, for each replicate, 10 agar blocks were examined using scanning electron microscopy.

\subsection{Transmission electron microscopy (TEM) observation}

According to the method of Benhamou et al. ${ }^{[18]}$, mycelial samples $(2 \mathrm{~mm})$ were excised from seven-day-old PDA cultures embedded with different concentrations $(0 \mu \mathrm{g} / \mathrm{mL}, 0.5 \mu \mathrm{g} / \mathrm{mL}, 0.75 \mu \mathrm{g} / \mathrm{mL}$ and $1.0 \mu \mathrm{g} / \mathrm{mL})$ of $\mathrm{ClO}_{2}$, and then immersed in $3 \%(\mathrm{v} / \mathrm{v})$ glutaraldehyde in $0.1 \mathrm{M}$ sodium cacodylate buffer, $\mathrm{pH}$ 7.2, for $2 \mathrm{~h}$ at room temperature. Samples were subsequently postfixed with $1 \%(\mathrm{w} / \mathrm{v})$ osmium tetroxide in the same buffer for $1 \mathrm{~h}$ at $4^{\circ} \mathrm{C}$ and dehydrated in Epon812. Sections $(0.7 \mu \mathrm{m})$ were cut from the Epon-embedded material using glass knives, mounted on glass slides and stained with $1 \%$ aqueous toluidine blue prior to examination with a Zeiss Axioscope microscope (Carl Zeiss, Inc., thornwood, NY) primarily for viewing the growth of fungal hyphae. Ultrathin sections $(0.1 \mu \mathrm{m})$ were collected on formvarcoated nickel grids and were contrasted with either uranyl acetate or lead citrate for direct examination under an electron microscope (JEM-1230, Japan) operating at $80 \mathrm{KV}$. Micrographs were taken with a CCD-Camera (America Gatan Company). Five samples from each sampling time were examined using five sections per sample.

\subsection{Effects of $\mathrm{ClO}_{2}$ on dry rot of potato tubers}

$\mathrm{ClO}_{2}$ treatments at $(0 \mu \mathrm{g} / \mathrm{mL}, 0.5 \mu \mathrm{g} / \mathrm{mL}, 0.75 \mu \mathrm{g} / \mathrm{mL}$ and $1.0 \mu \mathrm{g} / \mathrm{mL}$ ), were also applied to in vivo experiments. The tubers were wounded ( $5 \mathrm{~mm}$ deep and $3 \mathrm{~mm}$ wide) with a sterile nail at the equator, then, $10 \mu \mathrm{L}$ of a conidial suspension of $F$. sulphureum at $1 \times 10^{7}$ spores $/ \mathrm{mL}$ were added to each wound. Two hours after inoculation, tubers were dipped with $\mathrm{ClO}_{2}$ at different concentrations with sterile distilled water as the control. Treated tubers were put in $200 \mathrm{~mm} \times 130 \mathrm{~mm} \times 50 \mathrm{~mm}$ plastic boxes with sterile water in open petri dish to maintain a high relative humidity, then stored at room temperature $\left(20^{\circ} \mathrm{C}-22^{\circ} \mathrm{C}\right)$ and low temperature $\left(4^{\circ} \mathrm{C}-5^{\circ} \mathrm{C}\right)$. The incidence of decay at room temperature was determined $15 \mathrm{~d}$ after treatment 
and $45 \mathrm{~d}$ at low temperature. Each treatment contained 3 replicates with 12 tubers per replicate and the experiment was repeated twice.

\subsection{Statistical analysis}

Experiments were arranged in a completely randomized design, and each treatment was comprised of three replicates. Dates were tested by the analysis of variance using SPSS version 11.5 (SPSS Inc., Chicago, IL, USA). Least significant difference (LSDs) was calculated to compare significant effects at the 5\% level.

\section{Results and analysis}

\subsection{Inhibitory effect of $\mathrm{ClO}_{2}$ on growth of dry rot} pathogens of potato and indoor toxicity

In Table 1, the growth of F. sulphureum was strongly inhibited by $\mathrm{ClO}_{2}$ in a concentration-dependent manner. Growth of dry rot pathogens was significantly inhibited with the increasing concentration in the process, and complete inhibition at $1.25 \mu \mathrm{g} / \mathrm{mL}$. As shown in Figure 1, rapidly grown colonies with smooth and forward

mycelium were seen in control, but weak expansion in $\mathrm{ClO}_{2}$ treatments due to inhibition effect.

It can be seen from Table 2 qualitative data probability analysis in indoor bioassay that dry rot pathogen of potato is sensitive to $\mathrm{ClO}_{2}$ with $\mathrm{EC}_{50}$ and $\mathrm{EC}_{90}$ value of $0.3490 \mu \mathrm{g} / \mathrm{mL}$ and $0.6261 \mu \mathrm{g} / \mathrm{mL}$ respectively. The chi square value of fitting degree and its significant level values were 5.36 and 0.150239 respectively $(p<0.05)$, greater than 0.05 . This indicated that the toxicity regression curve and the established model are reasonable.

Table 1 Inhibition effect of $\mathrm{ClO}_{2}$ on mycelial growth of dry

\begin{tabular}{cccc}
\multicolumn{4}{c}{ rot pathogen of potato } \\
\hline $\begin{array}{c}\text { Chemical } \\
\text { treatment }\end{array}$ & $\begin{array}{c}\text { Concentration } \\
/ \mu \mathrm{g} \cdot \mathrm{mL}^{-1}\end{array}$ & $\begin{array}{c}\text { Antibacterial } \\
\text { circle diameter } / \mathrm{mm}\end{array}$ & $\begin{array}{c}\text { Relative inhibition } \\
\text { rate } / \%\end{array}$ \\
\hline & 0.25 & $30.0 \pm 0.5$ & $14.33 \mathrm{cb}$ \\
$\mathrm{ClO}_{2}$ & 0.50 & $54.6 \pm 0.3$ & $45.92 \mathrm{c}$ \\
& 0.75 & $61.0 \pm 0.0$ & $58.69 \mathrm{~b}$ \\
& 1.00 & $70.3 \pm 1.1$ & $78.32 \mathrm{~b}$ \\
$\mathrm{CK}$ & 1.25 & $80.0 \pm 0.0$ & $100.0 \mathrm{a}$ \\
\hline
\end{tabular}

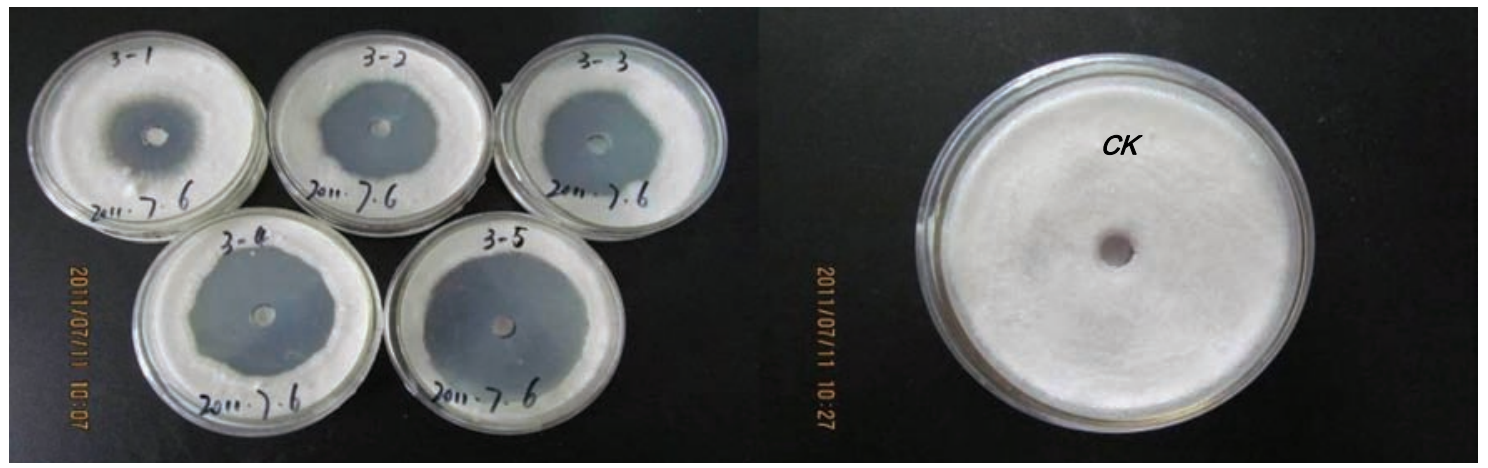

Figure 1 Toxic effect of $\mathrm{ClO}_{2}$ on dry rot in indoor bioassay

Table 2 Indoor bioassay of $\mathrm{ClO}_{2}$ to pathogens of potato dry rot

\begin{tabular}{ccccccc}
\hline Chemical & Regression equation & $\begin{array}{c}\mathrm{EC}_{50} \\
/ \mu \mathrm{g} \cdot \mathrm{mL}^{-1}\end{array}$ & $\begin{array}{c}\mathrm{EC}_{90} \\
/ \mu \mathrm{g} \cdot \mathrm{mL}^{-1}\end{array}$ & $\begin{array}{c}\text { Correlation } \\
\text { coefficient }\end{array}$ & $\begin{array}{c}\text { chi-square } \\
\text { value }\end{array}$ & $\begin{array}{c}95 \% \text { confidence level of } \\
\mathrm{EC50} \text { value }\end{array}$ \\
\hline $\mathrm{ClO}_{2}$ & $y=5.05+7.308 x$ & 0.3490 & 0.6261 & 0.9863 & 5.36 & $0.3225-0.3778$ \\
\hline
\end{tabular}

\subsection{Effects of $\mathrm{ClO}_{2}$ treatment on spore germination} and mycelial growth of $F$. sulphureum

Generally, the percentage of spore germination increased gradually with incubation time. Nearly all the spores in control without $\mathrm{ClO}_{2}$ addition were germinated after $8 \mathrm{~h}$ incubation (up to $91.6 \%$ ), however, only $18 \%$ of germination at $1.0 \mu \mathrm{g} / \mathrm{mL}$ of $\mathrm{ClO}_{2}$ were germinated (Figure 2a). The results indicated that the spore germination of $F$. sulphureum was significantly inhibited by different $\mathrm{ClO}_{2}$ concentrations $(p<0.05)$, and showed obvious concentration effect. In addition, the mycelial growth of $F$. sulphureum was also suppressed by $\mathrm{ClO}_{2}$ (Figure 2b). At the most effective concentration of $\mathrm{ClO}_{2}$, $1.0 \mu \mathrm{g} / \mathrm{mL}$ of the mycelial diameter was $87.5 \%$ smaller than the control.

\subsection{Changes in the hyphal morphology of $F$. sulphureum}

The morphology of $F$. sulphureum hyphae of $\mathrm{ClO}_{2}$ treatments with different concentrations were shown in Figure 3. By scanning electron micrographs (SEM) 
observation, hyphae of the control treatments were long, dense, uniform and round with a smooth surface (Figures 3a-3c). Whereas the growth of hyphae with $\mathrm{ClO}_{2}$ addition was strongly inhibited, as indicated by mycelial sparsity, asymmetry, curling, and twisting in Figures $3 \mathrm{~d}$, $3 \mathrm{j}$ and $3 \mathrm{~g}$. Newly developed hyphae were thinner and distorted with rough surfaces (Figures $3 \mathrm{e}, 3 \mathrm{~h}$ and $3 \mathrm{k}$ ). The hyphae were swollen and inflated at the brim and

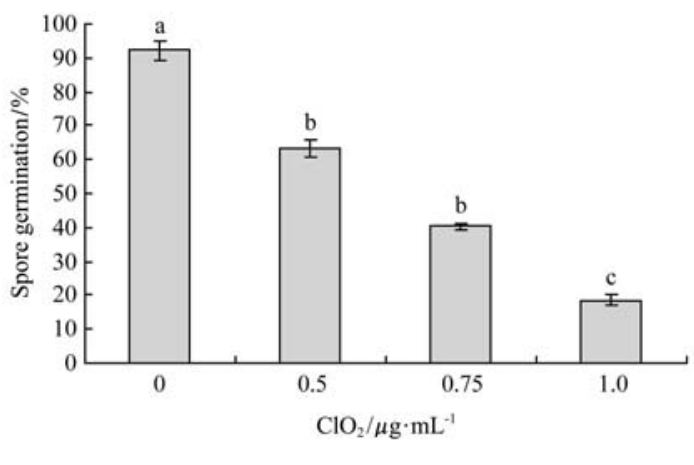

mycelium became blasted, wizened, and cupped (Figures $3 \mathrm{f}, 3 \mathrm{i}$ and 31). With the increasing concentration of $\mathrm{ClO}_{2}$, the hyphae appeared more winding at $0.75 \mu \mathrm{g} / \mathrm{mL}$ and $1.0 \mu \mathrm{g} / \mathrm{mL}$ of $\mathrm{ClO}_{2}$ than in control and $0.5 \mu \mathrm{g} / \mathrm{mL}$, it demonstrated that $\mathrm{ClO}_{2}$ evidently caused hyphae deformity. Furthermore, the edges of hyphae appeared irregular and swollen, while the hyphae branches were increased and collapsed in the present study.

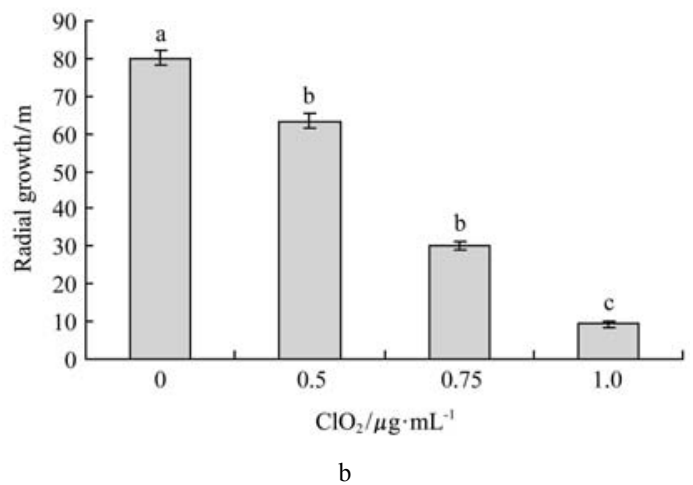

Figure 2 Effects of different $\mathrm{ClO}_{2}$ concentrations on spore germination (a) $8 \mathrm{~h}$ and mycelial growth (b) $7 \mathrm{~d}$ of F. sulphureum after incubation at $25^{\circ} \mathrm{C}$

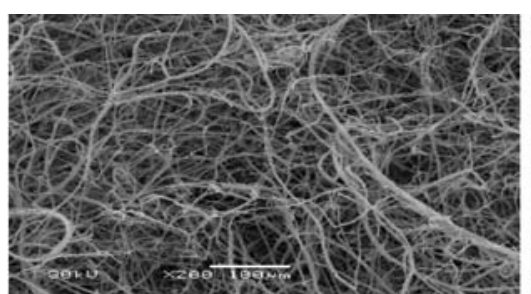

a. Control, scale bars represent $100 \mu \mathrm{m}$

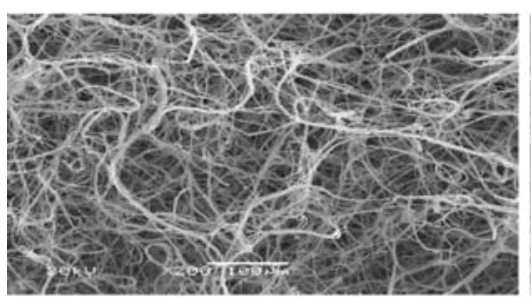

d. $0.5 \mu \mathrm{g} / \mathrm{mL}$, scale bars represent $100 \mu \mathrm{m}$

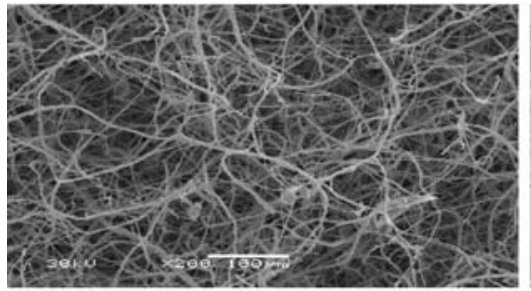

g. $0.75 \mu \mathrm{g} / \mathrm{mL}$, scale bars represent $100 \mu \mathrm{m}$

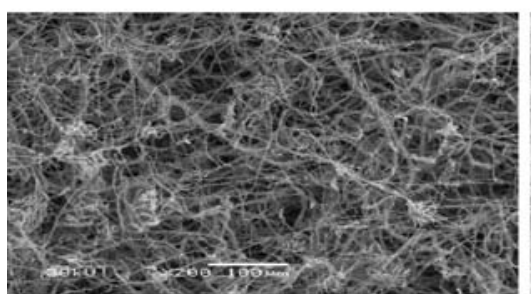

1. $1.0 \mu \mathrm{g} / \mathrm{mL}$, scale bars represent $100 \mu \mathrm{m}$

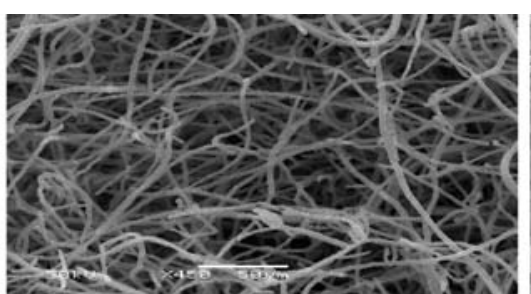

b. Control, scale bars represent $50 \mu \mathrm{m}$

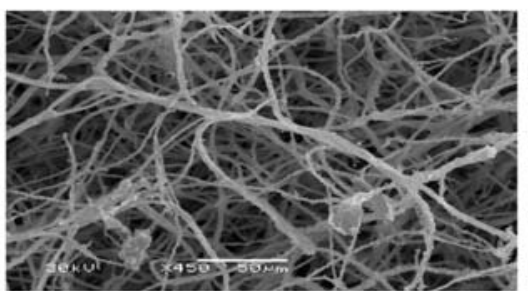

e. $0.5 \mu \mathrm{g} / \mathrm{mL}$, scale bars represent $50 \mu \mathrm{m}$

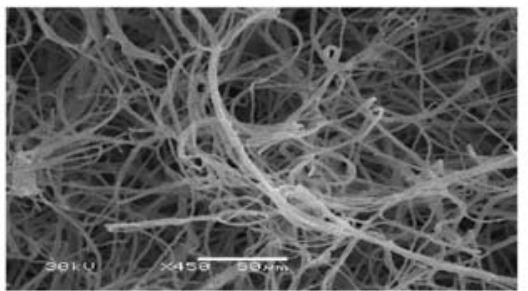

h. $0.75 \mu \mathrm{g} / \mathrm{mL}$, scale bars represent $50 \mu \mathrm{m}$

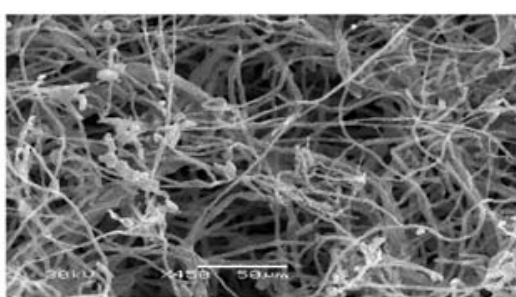

k. $1.0 \mu \mathrm{g} / \mathrm{mL}$, scale bars represent $50 \mu \mathrm{m}$

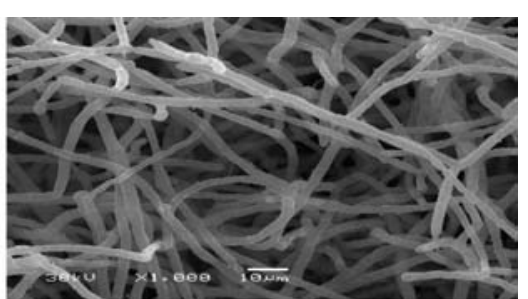

c. Control, scale bars represent $10 \mu \mathrm{m}$

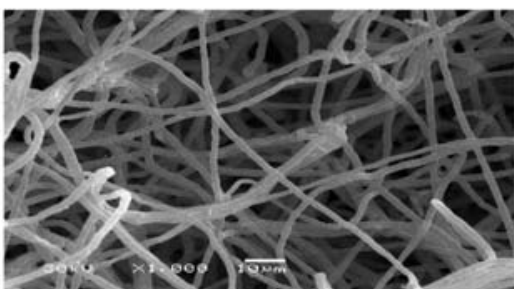

f. $0.5 \mu \mathrm{g} / \mathrm{mL}$, scale bars represent $10 \mu \mathrm{m}$

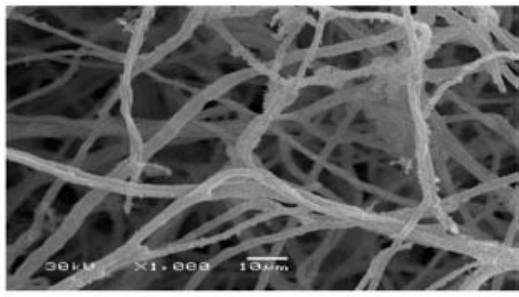

i. $0.75 \mu \mathrm{g} / \mathrm{mL}$, scale bars represent $10 \mu \mathrm{m}$

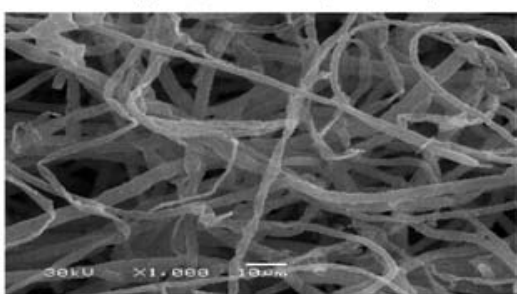

1. $1.0 \mu \mathrm{g} / \mathrm{mL}$, scale bars represent $10 \mu \mathrm{m}$

Figure 3 Scanning electron micrographs of the hyphae of $F$.sulphureum grown for $7 \mathrm{~d}$ on $\mathrm{PDA}$ plates containing by different $\mathrm{ClO}_{2}$ concentrations $(0 \mu \mathrm{g} / \mathrm{mL}, 0.5 \mu \mathrm{g} / \mathrm{mL}, 0.75 \mu \mathrm{g} / \mathrm{mL}, 1.0 \mu \mathrm{g} / \mathrm{mL})$ 
3.4 Changes in the hyphal ultrastructure of $F$. sulphureum

The ultrastructure of F.sulphureum in control and $\mathrm{ClO}_{2}$ treatments were shown in Figure 4. By transmission electron microscopy (TEM) observation, normally distributed cytoplasm and vacuoles cell were observed in control, and the hyphal cell wall was thin and uniform (Figures $4 a$ and $4 b$ ). In Figures $4 c$ and $4 d$, the cell wall of $0.5 \mu \mathrm{g} / \mathrm{mL} \quad \mathrm{ClO}_{2}$ treatment was irregularly thickened, and the daughter hyphae which were inside the collapsed hyphal cells were clearly detected. Besides, some of the daughter hyphae

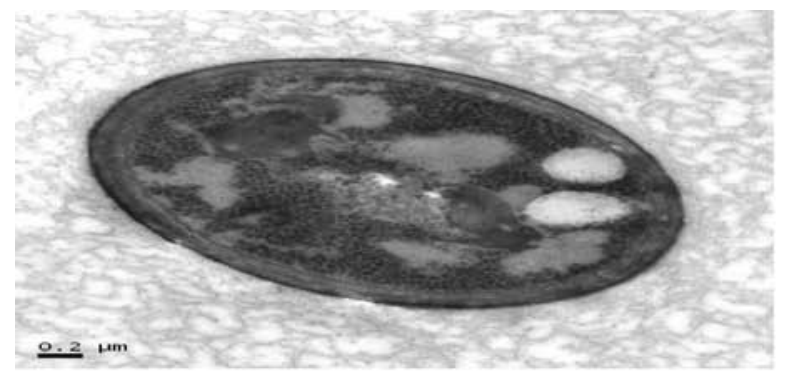

a. Control, scale bars represent $0.2 \mu \mathrm{m}$

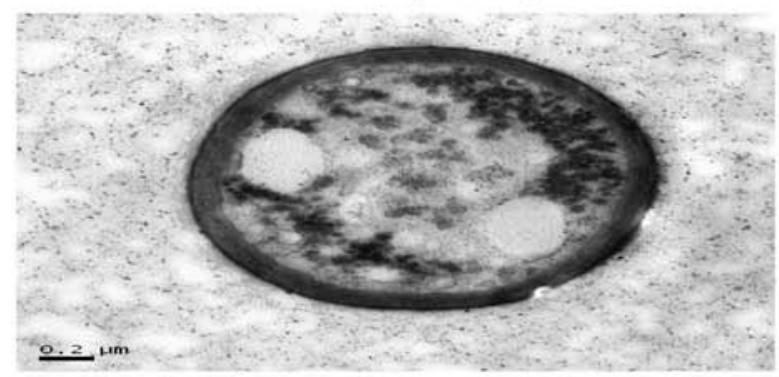

c. $0.5 \mu \mathrm{g} / \mathrm{mL}$, scale bars represent $0.2 \mu \mathrm{m}$

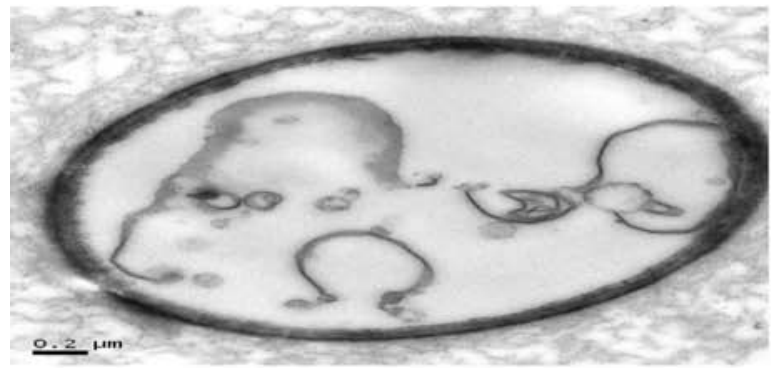

e. $0.75 \mu \mathrm{g} / \mathrm{mL}$, scale bars represent $0.2 \mu \mathrm{m}$

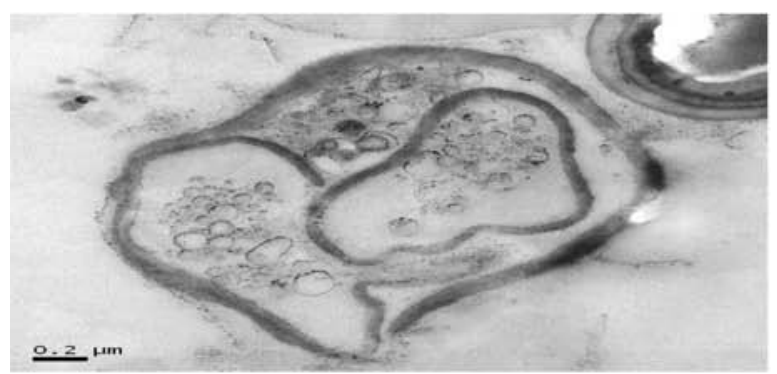

g. $1.0 \mu \mathrm{g} / \mathrm{mL}$, scale bars represent $0.2 \mu \mathrm{m}$ produced the new one, with even cytoplasm, electrondense material, or cavities. However, abnormally contracted and distorted cells were also found (Figures $4 \mathrm{c}$ and $4 \mathrm{~d}$ ). In $0.75 \mu \mathrm{g} / \mathrm{mL}$ and $1.0 \mu \mathrm{g} / \mathrm{mL} \mathrm{ClO}_{2}$ treatments (Figures $4 \mathrm{e}, 4 \mathrm{f}, 4 \mathrm{~g}$ and $4 \mathrm{~h}$ ), cell walls were obvious thickening, with electron-dense material in the cytoplasm and notably increasing distorted or unshaped hyphae. Electron-dense material in the cytoplasm and cavity were also observed in the longitudinal section of hyphae, but septa of $\mathrm{ClO}_{2}$ treated hyphae were uniform. In generally, the damage degree of hyphae was evidently related to $\mathrm{ClO}_{2}$ concentration.

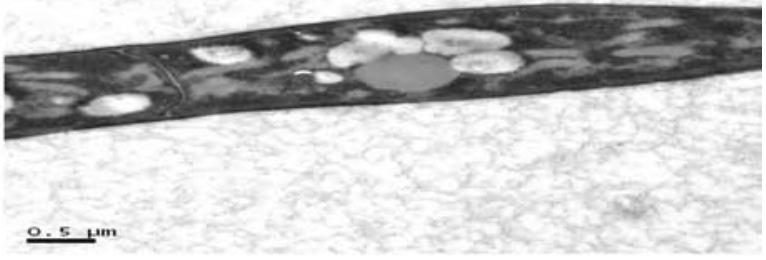

b. Control, scale bars represent $0.5 \mu \mathrm{m}$

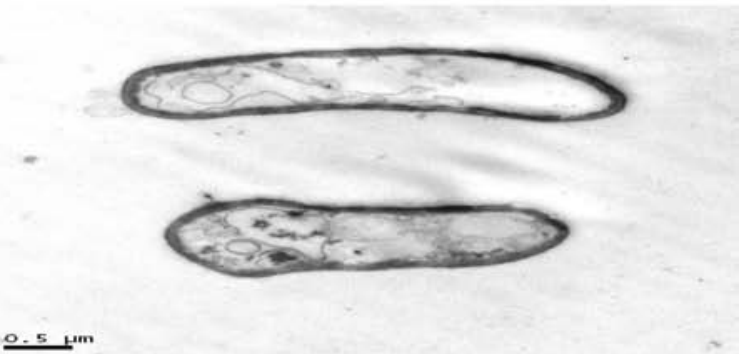

d. $0.5 \mu \mathrm{g} / \mathrm{mL}$, scale bars represent $0.5 \mu \mathrm{m}$

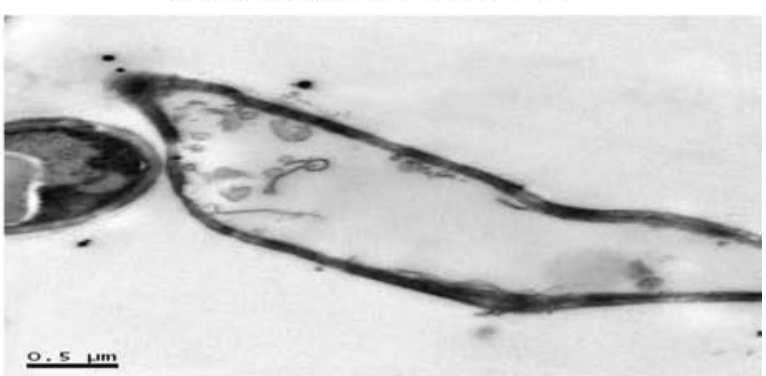

f. $0.75 \mu \mathrm{g} / \mathrm{mL}$, scale bars represent $0.5 \mu \mathrm{m}$

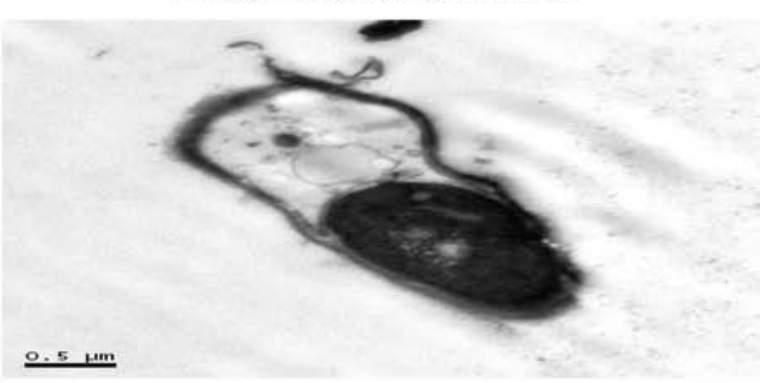

h. $1.0 \mu \mathrm{g} / \mathrm{mL}$, scale bars represent $0.5 \mu \mathrm{m}$

Figure 4 Transmission electron micrographs of the hyphae of F.sulphureum grown for $7 \mathrm{~d}$ on PDA plates containing by different $\mathrm{ClO}_{2}$ concentrations $(0 \mu \mathrm{g} / \mathrm{mL}, 0.5 \mu \mathrm{g} / \mathrm{mL}, 0.75 \mu \mathrm{g} / \mathrm{mL}$ and $1.0 \mu \mathrm{g} / \mathrm{mL})$ 


\subsection{Effects of $\mathrm{ClO}_{2}$ on dry rot of potato tubers}

To evaluate the curative effect of $\mathrm{ClO}_{2}$ against dry rot, potato tubers were artificial inoculated with $F$. sulphureum, and then dipped in different concentrations of $\mathrm{ClO}_{2}$ solution (Figure 5). The results showed that $\mathrm{ClO}_{2}$ could significantly $(p<0.05)$ reduce the dry rot development in potato tubers both at room temperature and low temperature. $\quad \mathrm{ClO}_{2}$ effectiveness increased up to the most effective concentration of $1.0 \mu \mathrm{g} / \mathrm{mL}$ at low temperature, where the lesion diameter of dry rot was only $4.93 \mathrm{~mm}$. In addition, the ability of $\mathrm{ClO}_{2}$ to control dry rot was enhanced when $\mathrm{ClO}_{2}$ concentration was increased from $0.5 \mu \mathrm{g} / \mathrm{mL}$ to $1.0 \mu \mathrm{g} / \mathrm{mL}$. However, no significant differences were found between $0.75 \mu \mathrm{g} / \mathrm{mL}$ and $1.0 \mu \mathrm{g} / \mathrm{mL} \mathrm{ClO}_{2}$ treatments.
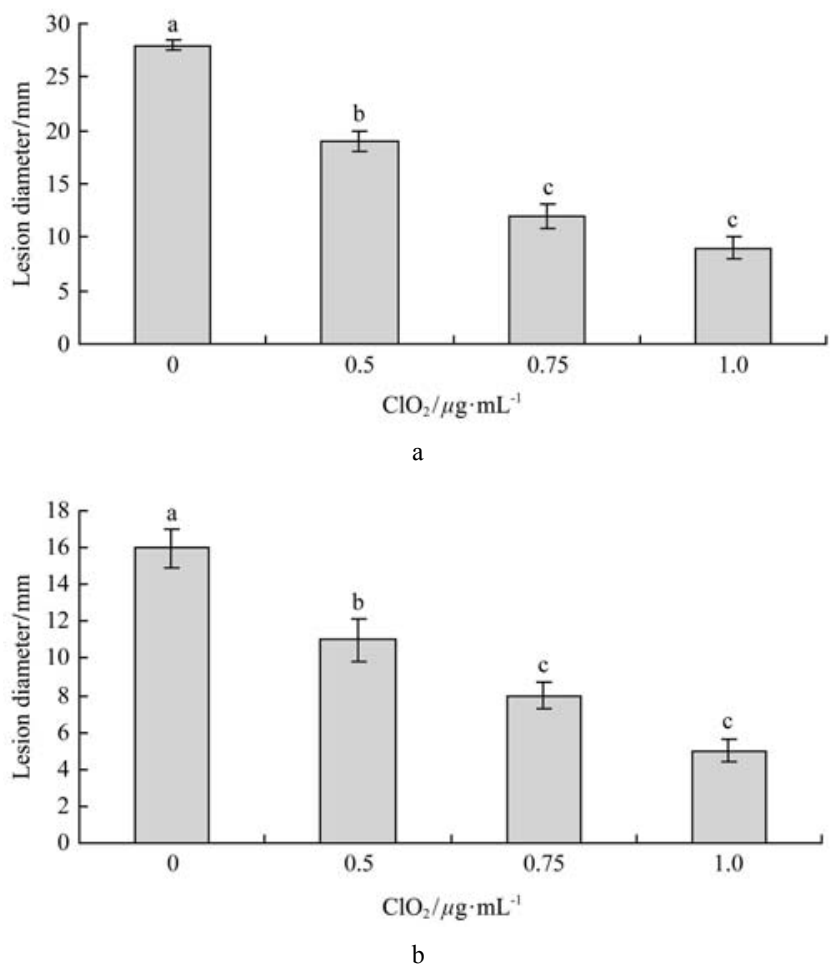

Figure 5 Effects of different $\mathrm{ClO}_{2}$ concentrations on lesion diameter of dry rot caused by $F$. sulphureum in inoculated potato tuber stored $15 \mathrm{~d}$ at room temperature $20^{\circ} \mathrm{C}-22^{\circ} \mathrm{C}$ (a) and $45 \mathrm{~d}$ at low temperature $4^{\circ} \mathrm{C}-5^{\circ} \mathrm{C}$ (b)

\section{Discussion}

$\mathrm{ClO}_{2}$ has been classified as A1 disinfection product by WHO and directly or indirectly used in food industries. It can effectively kill most microorganisms, including bacteria, fungi, algae, viruses, parasites, and is a high effective disinfectant internationally recognized ${ }^{[19-24]}$. The sturdy results provided conclusive evidence that postharvest treatment with $\mathrm{ClO}_{2}$ was effective for inhibiting pathogen growth as well as controlling dry rot in inoculated tubers, thereby decreasing the incidence of decay and maintaining tuber quality.

In this study, $\mathrm{ClO}_{2}$ directly inhibited the spore germination and mycelial growth of $F$. sulphureum in vitro (Figures 1 and 2). The result was consistent with the observation of $\mathrm{Li}$ et al. ${ }^{[25]}$ and $\mathrm{Hu}$ et al. ${ }^{[6]}$, who found that $100 \mathrm{mM}$ sodium silicate or $0.5 \mathrm{~g} / 100 \mathrm{~mL}$ to $1 \mathrm{~g} / 100 \mathrm{~mL}$ NO completely inhibited the mycelial growth of F.sulphureum Schlechlendahl, which are causative agent of Fusarium in potato, respectively. Similar results were also in accord with Chen et al. ${ }^{[27]}$, that $7 \mathrm{mg} / \mathrm{L} \quad \mathrm{ClO}_{2}$ effectively reduced the amount of S.cerevisae and F. tricinctum spores of 15 min treatment, respectively reduced by $5 \mathrm{lg}$ CFU and $4.6 \mathrm{lg}$ CFU. This indicated that $\mathrm{ClO}_{2}$ was fungistatic rather than fungicidal against $F$. sulphureum.

The antifungal mechanism of $\mathrm{ClO}_{2}$ was investigated using SEM and TEM. SEM observations showed that $\mathrm{ClO}_{2}$ could induced morphological changes such as twisted, wizened and irregular mycelium (Figure 3). Ultrastructural studies by TEM also indicated $\mathrm{ClO}_{2}$ caused fungal hyphal cells to be seriously damaged, including abnormal thickened cell wall, uneven cytoplasm and malformed hyphae (Figure 4). These results suggest two mechanisms whereby $\mathrm{ClO}_{2}$ may inhibit decay. Firstly, $\mathrm{ClO}_{2}$ has a toxicological outcome acting directly at the surface of the fungus, thus damaging the cell wall or membrane. This type of antifungal effect has been seen with boron and its ability to disrupt the cellmembrane of the $B$. cinerea, eventually leading to the leakage of cytoplasmic materials and death of the pathogen ${ }^{[26]}$. Secondly, $\mathrm{ClO}_{2}$ can act on the fungus at the intracellular level, by destroying its internal organelles or possibly interfering with the normal metabolism. This is in agreement with research by Lai et al. ${ }^{[27]}$ But this assumption needs further in-depth study.

Although no previous studies on changes in pathogen morphology and ultrastructure after $\mathrm{ClO}_{2}$ treatment have been undertaken, similar results were reported regarding the antifungal activities of NO, tebuconazole and 
chitosan ${ }^{[6,28,16]}$. The main fungistatic effects of $\mathrm{ClO}_{2}$ on $F$. sulphureum were changes to the structure of hyphal cells. Several reports indicated that $\mathrm{ClO}_{2}$ effectively control postharvest rots during storage, delay the onset of infection, and slow down the infection process. In general, the rots are well controlled with increasing $\mathrm{ClO}_{2}$ concentration. $\mathrm{ClO}_{2}$ application has been effective against postharvest diseases such as anthracnosis of Ficus carica $\operatorname{Linn}^{[29]}$, late bright, soft rot, silve scurf and bacterial ring rot of potato, and that $\mathrm{ClO}_{2}$ is currently the only marker for late blight control ${ }^{[30]}$. The results of the present experiment showed that $\mathrm{ClO}_{2}$ at $0.75 \mu \mathrm{g} / \mathrm{mL}$ was the most effective concentration in reducing decay, while a higher concentration $(1.0 \mu \mathrm{g} / \mathrm{mL})$ did not significantly increase disease control. This may be due to differences in the sensitivity of pathogen species to $\mathrm{ClO}_{2}$. However, the detailed mechanism for the preventive effect of $\mathrm{ClO}_{2}$ in our study needs further research.

\section{Conclusions}

Potato dry rot pathogen is sensitive to $\mathrm{ClO}_{2}$, spore germination and mycelium growth of $F$. sulphureum were strongly inhibited by $\mathrm{ClO}_{2}$ in a concentration-dependent manner, and clony morphology and ultrastructure of hyphae were damaged to some extent of dry rot pathogens of potato by $\mathrm{ClO}_{2}$.

$\mathrm{ClO}_{2}$ could effectively control the growth of $F$. sulphureum, cures and prevents dry rot of potato tubers, and $\mathrm{ClO}_{2}$ at the concentration of $0.75 \mu \mathrm{g} / \mathrm{mL}$ could significantly reduce the incidence of potato tuber dry rot and lesion expansion rate.

This study showed that $\mathrm{ClO}_{2}$ has good antibacterial effect to the pathogen of potato dry rot F.sulphureum, $\mathrm{ClO}_{2}$ could be used as a potential green fungicide, partially replace chemical synthetic fungicides, with a view to better control the disease of potatoes after harvest.

\section{Acknowledgements}

This work was supported by the Youth Fund Project of Gansu Academy of Agricultural Sciences (No. 2015GAAS23), Special Fund for China Agriculture Research System (Cars-10), Special Fund for
Agro-scientific Research in the Public Interest (201003077) and the National Natural Science Foundation of China (No. 31760476).

\section{[References]}

[1] Gabriella T, Matteo C, Nicola G, Antonella A, Mauro C, Renzo C. The content of selected minerals and vitamin C for potatoes (Solanum tuberosum L.) from the high Tiber Valley area, southeast Tuscany. Journal of Food Composition and Analysis, 2015; 41: 157-164.

[2] Yang Z M, Bi Y, Li Y C, Kou Z H, Bao G H, Liu C K, et al. Changes of cell wall degrading enzymes in potato tuber tissue slices infected by Fusarium sulphureum. Scientia Agricultura Sinica, 2012; 45(1): 127-134. (in Chinese)

[3] Li Y C, Bi Y, Ge Y H, Sun X J, Wang Y. Antifungal activity of sodium silicate on Fusarium sulphureum and its effect on dry rot of potato tubers. Journal of Food Science, 2009; 74(5): 213-218.

[4] Bi Y, Li Y C, Ge Y H. Induced resistance in postharvest fruits and vegetables by chemicals and its mechanism. Stewart Postharvest Review, 2007; 3(6): 1-7.

[5] Sun X J, Bi Y, Li Y C, Han R F, Ge Y H. Postharvest chitosan treatment induces resistance in potato against Fusarium sulphureum. Agricultural Sciences in China, 2008; 7: 615-621.

[6] Hu L G, Li Y C, Bi Y, Li J P, Bao G H, Liu J J, et al. Effects of nitric oxide on growth of Fusarium sulphureum and its virulence to potato tubers. European Food Research and Technology, 2014; 238(6): 1007-1014.

[7] Zhang Q C, Li Y C, Bi Y, Sun X J, Wang H J. The inhibiting effect of postharvest citric acid treatment on dry rot of wounded-inoculated potato and the activity of defense enzymes. Journal of Gansu Agricultural University, 2009; 3 146-150. (in Chinese)

[8] Mur L A, Mandon J, Persijn S, Cristescu S M, Moshkov I E, Novikova G V, et al. Nitric oxide in plants: an assessment of the current state of knowledge. AoB Plants, 2013; 5: pls052.

[9] Tossi V, Amenta M, Lamattina L, Cassia R. Nitric oxide enhances plant ultraviolet-B protection up-regulating gene expression of the phenylpropanoid biosynthetic pathway. Plant, Cell \& Environment, 2011; 34(6): 909-921.

[10] Schairer D O, Chouake J S, Nosanchuk J D, Friedman A J. The potential of nitric oxide releasing therapies as antimicrobial agents. Virulence, 2012; 3(3): 271-279.

[11] Lai T F, Li B Q, Qin G Z, Tian S P. Oxidative damage involves in the inhibitory effect of nitric oxide on spore germination of Penicillium expansum. Current Microbiology, 2011; 62(1): 229-234. 
[12] Chen S F, Guo P Y, Ruan B. Effects of stable chlorine dioxide on chlorophyll a and antioxiant enzymes of Microcystis flos-aquae. Journal of Central South University (Science and Technology), 2016; 47(2): 414-419. (in Chinese)

[13] Gómez-López V M, Devlieghere F, Ragaert P, Debevere J. Shelf-life extension of minimally processed carrots by gaseous chlorine dioxide. International Journal of Food Microbiology, 2007; 116 (2): 221-227.

[14] Li J K, Zhang P, Zhang P. Research progress in application of chlorine dioxide in fruit fresh-keeping. Science and Technology of Food Industry, 2011; 32(9): 439-442. (in Chinese)

[15] Zhang X, Wang X L, Plant Chemical Protection Experiment Iinstruction. Yangling: Northwest Agriculture and Forestry University of Science and Technology Press, 2000; pp.64-66. (in Chinese)

[16] Li Y C, Sun X J, Bi Y, Ge Y H, Wang Y. Antifungal activity of chitosan on Fusarium sulphureum in relation to dry rot of potato tuber. Agricultural Sciences in China, 2009; 8(5): 597-604.

[17] Yao H J, Tian S P. Effects of a biocontrol agent and methyl jasmonate on postharvest diseases of peach fruit and the possible mechanisms involved. Journal of Applied Microbiology, 2005; 98(4): 941-950.

[18] Benhamou N, Rey P, Picard K, Tirilly Y. Ultrastructural and cytochemical aspects of the interaction between the mycoparasite Pythium oligandrum and soilborne plant pathogens. Phytopathology, 1999; 89(6): 506-517.

[19] Huang J L, Wang L, Ren N Q, Ma F, Ju L, Liu X L, et al. Disinfection effect of chlorine dioxide on viruses, algae and animal planktons in water. Water Research, 1997; 31(3): 455-460.

[20] Tian C H, Ma X Y, Xu X F. The disinfection effect of chlorine dioxide on Pathogenes of Silkworm, Bombyx Mori L. Journal of Anhui Agricultural University, 1996; 4: 525-528. (in Chinese)

[21] Winiecka-Krusnell J, Linder E. Cysticidal effect of chlorine dioxide on Giardia intestinalis cysts. Acta Tropica, 1998; 70(3): 369-372.

[22] Lu C Y, Deng X Q, Zhao M, Zhou X P. Examination of efficacy of chlorine dioxide solution in killing skin fungi. Journal of Chinese Disinfection, 2000; 17(4): 227-229. (in Chinese)

[23] Li J W, Xin Z T, Wang X W, Zheng J L, Chao F H. Mechanisms of inactivation of hepatitis A virus in water by chlorine dioxide. Water Research, 2004; 38(6): 1514-1519.

[24] Deng J H, Wu Q P, Que S H, Zheng W H, Liao F Y. Experimental observation on efficacy of chlorine dioxide in killing Chlorella. Chinese Journal of Disinfection, 2005; 22(3): 282-283. (in Chinese)

[25] Li Y C, Bi Y, Ge Y H, Sun X J, Wang Y. Antifungal activity of sodium silicate on Fusarium sulphureum and its effect on dry rot of potato tubers. Journal of Food Science, 2009; 74(5): 213-218.

[26] Qin G Z, Zong Y Y, Chen Q L, Hua D L, Tian S P. Inhibitory effect of boron against Botrytis cinerea on table grapes and its possible mechanisms of action. International Journal of Food Microbiology, 2010; 138(1-2): 145-150.

[27] Lai T F, Li B Q, Qin G Z, Tian S P. Oxidative damage involves in the inhibitory effect of nitric oxide on spore germination of Penicillium expansum. Current Microbiology, 2011; 62(1): 229-234.

[28] Kang Z S, Huang L L, Krieg U, Mauler-Machnik A, Buchnauer H. Effects of tebuconazole on morphology, structure, cell wall components and trichothecene production of Fusarium culmorum in vitro. Pest Management Science, 2001; 57(6): 491-500.

[29] Ait Barka E, Eullaffroy P, Clement C, Vernet G. Chitosan improves development, and protects Vitis vinifera L. against Botrytis cinerea. Plant Cell Reports, 2004; 22(8): 608-614.

[30] Karabulut O A, Ilhan K, Arslan U, Vardar C. Evaluation of the use of chlorine dioxide by fogging for decreasing postharvest decay of fig. Postharvest Biology and Technology, 2009; 52(3): 313-315. 